\title{
Erratum to: Necrotising Fasciitis of the Neck and Anterior Chest Wall
}

\author{
Sonali Prabhakar Khadakkar • Vivek V. Harkare • \\ Nitin V. Deosthale $\cdot$ Ashish Gupta
}

Published online: 3 August 2011

(C) Association of Otolaryngologists of India 2011

Erratum to: Indian J Otolaryngol Head Neck Surg

DOI 10.1007/s12070-011-0209-7

Unfortunately Nitin V. Deosthale and Ashish Gupta were not included as authors in the orginal version by mistake. Please find here the correct author group of the article.

The online version of the original article can be found under doi:10.1007/s12070-011-0209-7.

S. P. Khadakkar $(\bowtie) \cdot$ V. V. Harkare · N. V. Deosthale .

A. Gupta

N.K.P. Salve Institute of Medical Sciences,

Nagpur 440019, Maharashtra, India

e-mail: sonalikhadakkar@yahoo.com 